\title{
APPLICATION OF STABLE ISOTOPES TO EVALUATE THE INTERACTION BETWEEN SURFACE WATER AND GROUNDWATER IN NORTH EAST OF DIYALA, IRAQ
}

\author{
${ }^{1}$ Kamal B. Nada*, ${ }^{2}$ Ali R. Ajeena, ${ }^{2}$ Al-Kubaisi Q.Yassian, ${ }^{1}$ Ali H. Falih and ${ }^{1}$ Adwia Abd \\ AlSalam, ${ }^{1}$ Ali Abass, ${ }^{1}$ Amer Abd and ${ }^{2}$ Eman Hameed \\ ${ }^{1}$ Environment and Water Directorate, Ministry of Science and Technology, Baghdad, Iraq \\ ${ }^{2}$ Department of Geology, College of Science, University of Baghdad, Baghdad, Iraq \\ *E-Mail: Kamalalparuany@yahoo.com \\ Received: 24 May 2020; accepted: 4 November 2020
}

\begin{abstract}
It had been adopted two reliable techniques which are hydro-chemical and stable isotopes to study the interaction between groundwater and surface water in Wand dam northeastern of Diyala. Eighteen water samples were collected from Wand dam, piezometers, groundwater pumping wells, spring, accumulation basins and irrigation water during two periods; June and November 2017. The concentrations of cations in Wand dam water order to $\mathrm{Ca}^{2+}>\mathrm{Na}^{+}>$ $\mathrm{Mg}^{2+}>\mathrm{K}^{+}, \mathrm{SO}_{4}>\mathrm{Cl}^{-}>\mathrm{HCO}_{3}^{-}$. The concentrations of cations in the samples collected from groundwater, irrigation water, springs and accumulation basins order to $\mathrm{Na}>\mathrm{Ca}>\mathrm{Mg}^{2+}>\mathrm{K}^{+}$, $\mathrm{Ca}^{2+}>\mathrm{Na}^{+}>\mathrm{Mg}^{2+}>\mathrm{K}^{+}, \mathrm{Na}^{+}>\mathrm{Ca}^{2+}>\mathrm{Mg}^{2+}>\mathrm{K}^{+}$and $\mathrm{Ca}^{2+}>\mathrm{Na}^{+}>\mathrm{Mg}^{2+}>\mathrm{K}^{+}$respectively and the anions concentrations have order $\mathrm{Cl}->\mathrm{SO}_{4}>\mathrm{HCO}_{3}-, \mathrm{SO}_{4}->\mathrm{Cl}->\mathrm{HCO}_{3}, \mathrm{Cl}->\mathrm{SO}_{4}>\mathrm{HCO}_{3}$ and $\mathrm{SO}_{4}->\mathrm{Cl}->\mathrm{HCO}_{3}-$ in groundwater, irrigation water, springs and accumulation basins respectively. There are three groups of water types based on isotopic composition; group A which noted in the Wand dam water, the piezometers Nos. 3 and 4, accumulation basin No.7 and irrigation water. Versus standards Group A is enriched by deuterium and oxygen-18, which show the effect of evaporation. Group B is distinguished by isotopic composition enrichment in groundwater as well as piezometer No. 7 than other piezometers due to difference of wells depth. Group C shows that the water samples collected from accumulation basin No.1 and springs have enriched stable isotopes. There is spatial and temporal variation of isotopic contents and hydro-chemical properties of water samples which could be due to different recharge sources, evaporation processes and origin of water. Based on concluded information, there is no evidence prove any interconnection between the water of Wand dam and other water resources, except piezometer No. 5 which could be because presence the permeable bed.
\end{abstract}

Keywords: Stable isotopes; Hydrochemistry; Groundwater; Surface water 


\section{INTRODUCTION}

Many parts of the world, water demand consistently exceeds water supply, especially in the arid and semi-arid regions (Barnett, 2005 and Immerzeel, 2010). Numerous researches have been done on the groundwater-surface water interactions (Clark and Fritz, 1997; Ortega, 2003 and Kalbus et al., 2006), generally focusing on areas such as sources of water, hydrologic interchanges, and exchange properties of water quality and quantity (Bath, 2006 and Liao et al., 2018). The most frequently used approaches of environmental isotopic tracers (hydrogen and oxygen) (Schmiedl et al., 2004), hydrochemical study (Applo and Postmad, 2005), recharge sources (Clark and Fritz, 1997), water interaction (Zhuo, 2016). In Iraq some studies such as Ali (2012), Al Paruany (2013), Ajena (2014), Ali and Ajena (2016), Al-Khafagi, (2018) and Abbas (2019). All these researches deal with interaction of groundwater and surface water, while many studies for hydrology and hydrogeology are conducted in the study area (Parsons, 1955; Al-Jiburi, 1991; Ahmed et al., 2005 and Esmail, 2012). Hadi and Alwan (2020) studied the surface- ground water interactions in Diwaniya, southern Iraq using isotopic and mentioned that the hydrochemical study confirmed that there are interactions between groundwater and surface water in the selected region. It was observed that all stable isotope results were near to the GMWL, meaning that the rainfall contributes effectively to feed the river and groundwater in the region. Awadh et al., 2016 studied the ground water in Al-Hawija area and mentioned that the ground water is poor, very poor and unsuitable for human drinking which distributed in wells that are nearby the discharge channel carrying deteriorated water. Jumaah and Al-Shammaa (2020) mentioned that the groundwater in the study area is believed to be affected by the Euphrates river level, therefore, the salinity during the low river level season is greater than during the high river level season. The present paper aims to investigate the interaction between Wand Dam and groundwater in the Wand Basin using hydrochemical and isotope techniques.

\section{STUDY AREA}

Wand Dam is located about $133 \mathrm{~km}$ north east Baghdad with coordinates latitudes $\left(34^{0} 14^{\prime}\right.$ $\left.30.5^{\prime \prime}-34^{0} 26^{\prime} 00^{\prime \prime}\right)$ and longitudes (45 $11^{\prime} 40^{\prime \prime}-45^{0} 32^{\prime} 00^{\prime \prime}$ ) (Fig. 1). It has an area of approximately $3800 \mathrm{~m}$ length, $12 \mathrm{~m}$ width and the level of 146.5 meters above Sea level. The operational attribution of the dam is $131.5 \mathrm{~m}$ with storage capacity of 1.5 billion cubic meters. Al -Wand River, tributary of the Diyala River, originates from Iranian lands and passes through Khanaqin City. The operation and maintenance works are managed by the Ministry of Water Resources. The Wand basin area is located within arid to semi-arid region, annually, 
an average evaporation of about $479 \mathrm{~mm}$. The mean annual air temperature and precipitation in the study area are about $34^{\circ} \mathrm{C}$ and $48 \mathrm{~mm}$, respectively. The study area's geology stratigraphy is divided into the Mukdadyia Formation (lower Pliocene), Bai Hassan Formation (upper Pliocene) and Quaternary deposits (Pleistocene- Holocene). The Mukdadyia Formation is considered the oldest formation within the study area, made up of alternation of sandstone and sometime it mixed with gravel and mudstone.

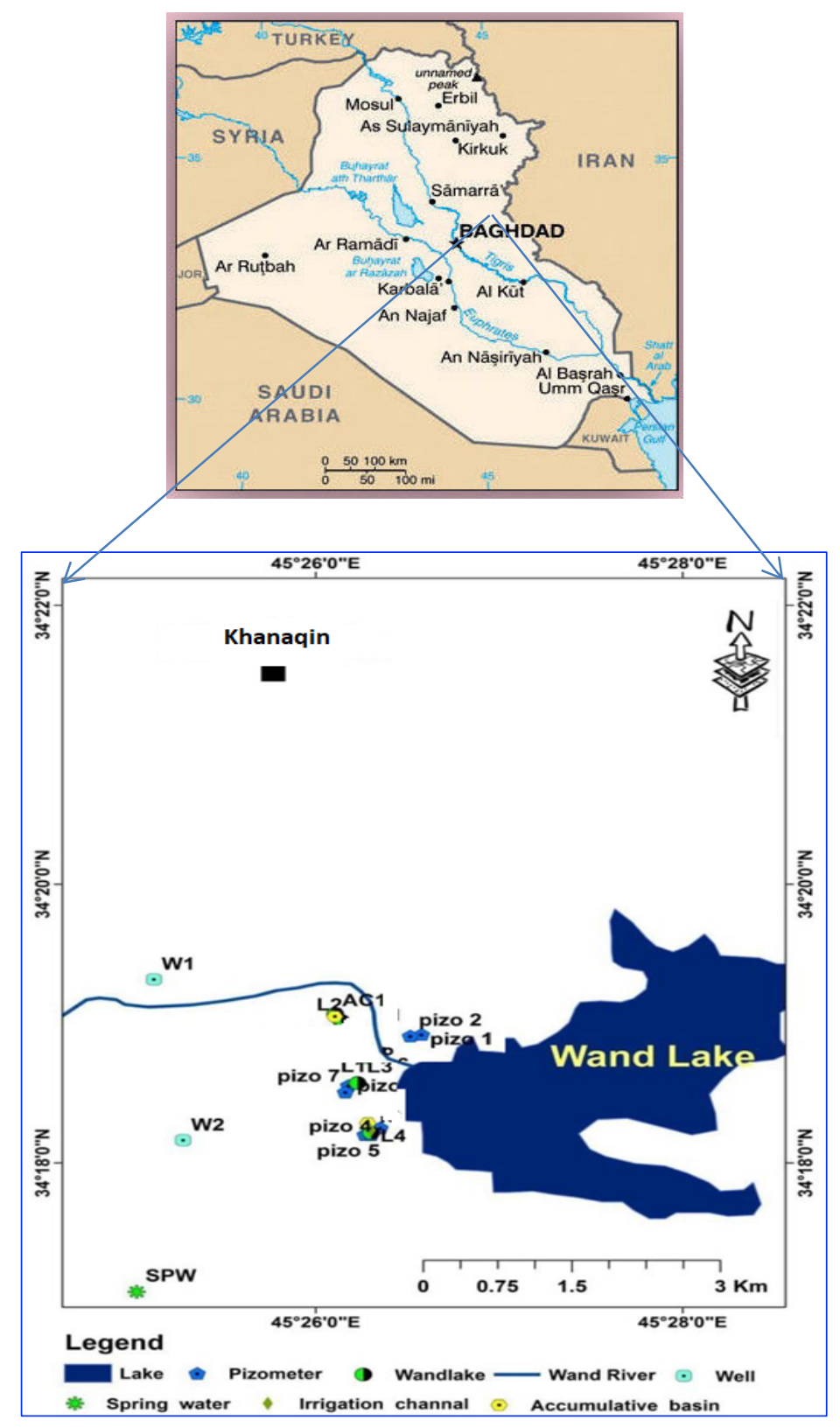

Fig. 1. Location of the study area

\section{MATERIALS AND METHODS}

Eighteen water samples have been collected from the Wand dam, groundwater pumping wells, piezometers, springs and accumulation basins during June and November 2017 to 
analyze the major elements and stable isotopes (Table 1). Field Measurements EC and pH were done in the site, cations and anions were measured in the lab according to APHA, 2012. Deuterium $\left(\delta^{2} \mathrm{H}\right)$ and oxygen-18 $\left(\delta^{18} \mathrm{O}\right)$ have been measured in the directorate of Environment and Water in Ministry of Science and Technology using a Liquid-Water Stable Isotope Analyser (LWSIA). Precisions of analysis equal to \pm 1.0 for $\delta{ }^{2} \mathrm{H}$ and \pm 0.1 for $\delta^{18} \mathrm{O}$. Deuterium and Oxygen-18 are reported in the conventional delta notation $\left(\delta^{2} \mathrm{H}\right.$ and $\left.\delta 18 \mathrm{O}\right)$ relative to Vienna Standard Mean Ocean Water (VSMOW) (IAEA, 2005). The volumes of sample are $500 \mathrm{ml}$ for isotopes analysis using polyethylene bottles and $50 \mathrm{ml}$ for major ions using glass bottles. The sample bottles have been sealed immediately and stored at $4{ }^{\circ} \mathrm{C}$ until analysis.

Table 1. Location of sampling points in the study area

\begin{tabular}{|c|c|c|c|c|c|c|}
\hline Locations & Symbol & Elevation & Static level & Well depth & Latitude & Longitude \\
\hline Piezometer No. 1 & pizo 1 & 218 & & 28 & $45^{0} 26^{\prime} 29.7^{\prime \prime}$ & $34^{0} 19^{\prime} 7.1^{\prime \prime}$ \\
\hline Piezometer No.2 & pizo 2 & 204.05 & & 22 & $45^{0} 26^{\prime} 25^{\prime \prime}$ & $34^{0} 19^{\prime} 0.1^{\prime \prime}$ \\
\hline Piezometer No.3 & pizo 3 & 209.5 & & 28 & $45^{0} 26^{\prime} 26.1^{\prime \prime}$ & $34^{0} 18^{\prime} 59.1^{\prime \prime}$ \\
\hline Piezometer No.4 & pizo 5 & 200.5 & & 30 & $45^{0} 2620.6^{\prime \prime}$ & $34^{0} 18^{\prime} 49.4^{\prime \prime}$ \\
\hline Piezometer No.5 & pizo 6 & 209.8 & & 28 & $45^{0} 26^{\prime} 21.3^{\prime \prime}$ & $34^{0} 18^{\prime} 49.1^{\prime \prime}$ \\
\hline Piezometer No.6 & pizo 7 & 220.08 & & 28 & $45^{0} 26^{\prime} 22.2^{\prime \prime}$ & $34^{0} .18 .48 .9^{\prime \prime}$ \\
\hline Piezometer No.7 & pizo 8 & 260.38 & & 24 & $45^{\circ} 26^{\prime} 19.1^{\prime \prime}$ & $34^{0} 18^{\prime} 46.1^{\prime \prime}$ \\
\hline Spring & SPW & 255 & & - & $45^{0} 25^{\prime} 47.1^{\prime \prime}$ & $34^{0} 17^{\prime} 45.4^{\prime \prime}$ \\
\hline Wand lake - Front Side & L1 & 265 & & - & $45^{0} 2^{\prime} 637.6^{\prime \prime}$ & $34^{0} 19^{\prime} 11.4^{\prime \prime}$ \\
\hline Wand lake - Right Side & L2 & 265 & & - & $45^{0} 26^{\prime} 38.8^{\prime \prime}$ & $34^{0} 19^{\prime} 13.1^{\prime \prime}$ \\
\hline Wand lake - Left Side & L3 & 265 & & - & $45^{0} 26^{\prime} 22.5^{\prime \prime}$ & $34^{0} 26^{\prime} 22.5^{\prime \prime}$ \\
\hline Wand lake - Center & L4 & 265 & & - & $45^{0} 26^{\prime} 23.3^{\prime \prime}$ & $34^{0} 1827.2^{\prime \prime}$ \\
\hline accumulative basin No. 1 & $\mathrm{AC} 1$ & 230 & & - & $45^{0} 26^{\prime} 26.6^{\prime \prime}$ & $34^{0} 19^{\prime} 30.0^{\prime \prime}$ \\
\hline Accumulative basin No. 7 & $\mathrm{AC7}$ & 231 & & - & $45^{\circ} 26^{\prime} 19.2^{\prime \prime}$ & $34^{0} 18^{\prime} 50.6^{\prime \prime}$ \\
\hline Arian Well & W1 & 212 & 190 & 62 & $45^{0} 25^{\prime} 1.7^{\prime \prime}$ & $34^{0} 19^{\prime} 19^{\prime \prime}$ \\
\hline Hazam Well & W2 & 213 & 178 & 70 & $45^{0} 25^{\prime} 17.8^{\prime \prime}$ & $34^{0} 18^{\prime} 32.8^{\prime \prime}$ \\
\hline Well 3 & W3 & 211 & 184 & 30 & $45^{0} 24^{\prime} 28,3^{\prime \prime}$ & $34^{0} 18^{\prime} 43.8^{\prime \prime}$ \\
\hline Well Official & W4 & 211.3 & 176 & 60 & $45^{0} 24^{\prime} 1.5^{\prime \prime}$ & $34^{0} 18^{\prime} 51.5^{\prime \prime}$ \\
\hline Irrigation Water & $\mathrm{IC}$ & 255 & & & $45^{0} 26^{\prime} 18.3^{\prime \prime}$ & $34^{0} 18^{\prime} 46.3^{\prime \prime}$ \\
\hline
\end{tabular}

\section{RESULTS AND DISCUSSION}

\section{Chemical Evaluation}

The $\mathrm{pH}$ of Wand dam water ranges from 7.57 to 7.9 and from 7 to 11.68 in the water of accumulation basins. From other side, $\mathrm{pH}$ ranges from 6.86 to 7.2 in groundwater samples collected from pumping wells and piezometers, while it equals to 7.53 in irrigation water during June 2017. The values of $\mathrm{pH}$ during November 2017 range from 7.5 to 7.6 in Wand dam water, 6.9 to 7 in Accumulative Basin, 7.4 to 9.5 in the piezometers and pumping wells, and 7.3 in irrigation water. The values of electrical conductivity (EC) in the Wand dam water, accumulation basin, piezometer well, groundwater pumping wells were and irrigation water 
were $(980-990 \mu \mathrm{s} . \mathrm{cm}-1),\left(1368-3450 \mu \mathrm{s.cm}^{-1}\right),(9530-15000 \mu \mathrm{s} . \mathrm{cm}-1)$ and $(2020-3780 \mu \mathrm{s} . \mathrm{cm}-1$. The ranges values of EC of the Wand dam water, accumulation basins, piezometer wells, groundwater pumping wells and irrigation water were 864-869 $\mu$ s.cm-1, 1234-2234 $\mu$ s.cm${ }^{1}, 8900-13232 \mu{\mathrm{s} . \mathrm{cm}^{-}}^{1}$ and $1987-3578 \mu \mathrm{s} . \mathrm{cm}-1$, in the November, 2017. The ranges of Total Dissolved Solid (TDS) of the Wand dam water, water accumulation basin, piezometer well, groundwater pumping wells and irrigation water were 593-598ppm, 545-1050ppm, 925-5400ppm,1596-1905 ppm, and 793ppm, Respectively in the June, 2017 while, The ranges of TDS of the Wand dam water, accumulation basins, piezometer wells, groundwater pumping wells and irrigation water were 520-540ppm, 590-900ppm, 775$5125 \mathrm{ppm}$ and 645ppm, in the November 2017. The decreases in EC value of the Wind Dam water means there is a water quality variation. Mean EC values of Wand water $(985 \mu \mathrm{S} / \mathrm{cm})$ and groundwater pumping wells $(3432 \mu \mathrm{S} / \mathrm{cm})$ were different to each other, refers to there is no connection of the two water bodies. In the current study, the cations and anions of AlWand water, piezometers well and groundwater pumping wells had similar trends as TDS (Figs. 2 and 3). The major ions of water samples collected over the study area are listed in Table 2.

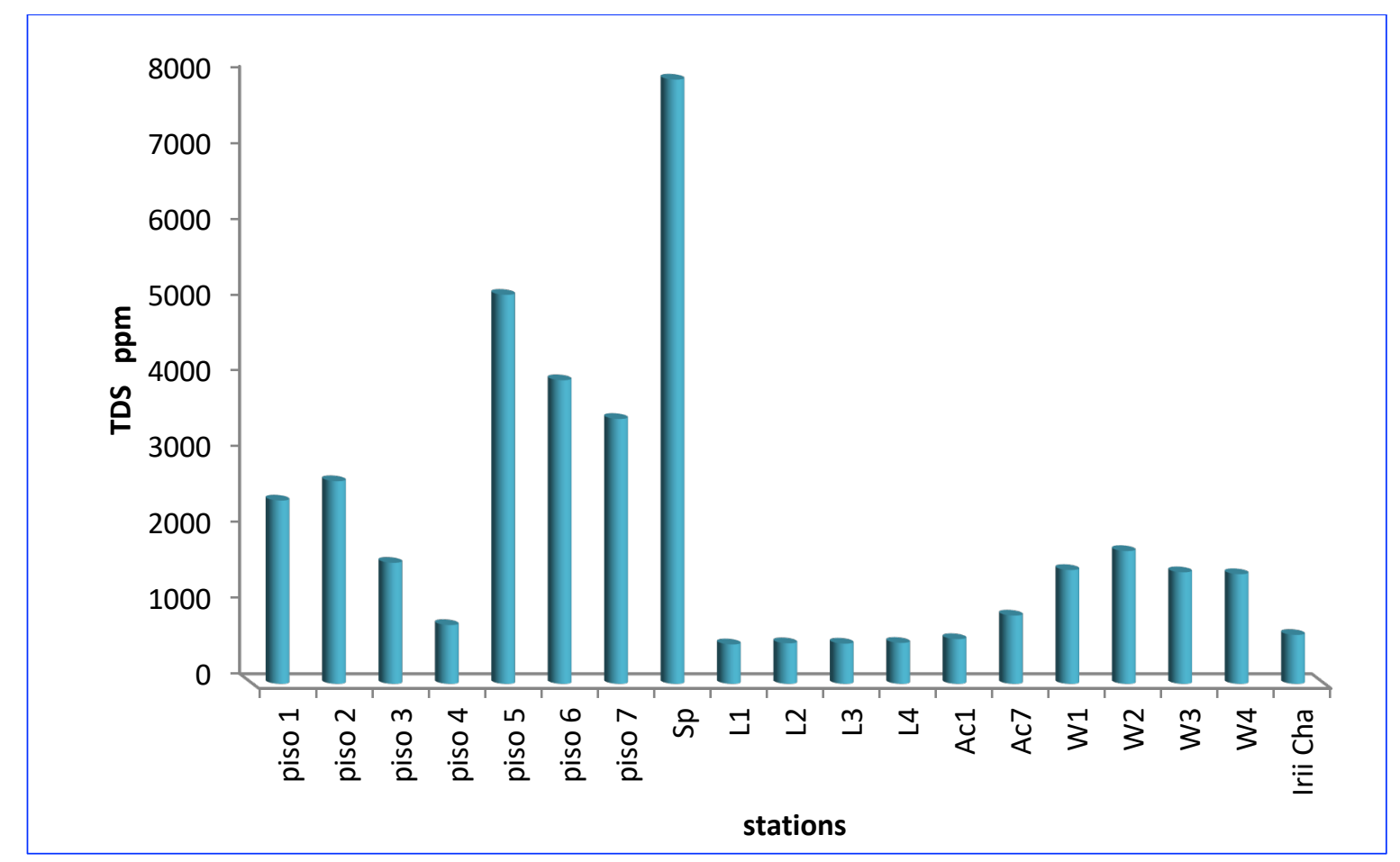

Fig. 2. Distribution of TDS of water sample in the study area during November, 2017 
Table 2. Physical - chemical parameters of water samples in the study area

\begin{tabular}{|c|c|c|c|c|c|c|c|c|c|c|c|c|}
\hline \multicolumn{2}{|l|}{ Stations } & pH & Ec & TDS & $\mathbf{C a}$ & Mg & $\mathbf{N a}$ & $\mathbf{K}$ & Cl & $\mathrm{SO}_{4}$ & $\mathrm{HCO}_{3}$ & $\mathrm{CO}_{3}$ \\
\hline \multicolumn{13}{|c|}{ June, 2017} \\
\hline \multirow[t]{7}{*}{ piezometers } & pizo 1 & 7.47 & 4810 & 2565 & 460 & 123 & 565 & 1030 & 399.8 & 1010 & 122 & 6 \\
\hline & pizo 2 & 9.1 & 4600 & 2725 & 430 & 80 & 490 & 1008 & 450 & 1008 & 366 & 18 \\
\hline & pizo 3 & 10.5 & 3440 & 1760 & 280 & 63 & 412 & 700 & 350 & 990 & 48.8 & 42 \\
\hline & pizo 5 & 7.87 & 1720 & 925 & 140 & 44 & 110 & 360 & 110 & 412 & 200 & 6 \\
\hline & pizo 6 & 11.68 & 15000 & 5400 & 870 & 190 & 379.8 & 2650 & 379.8 & 2650 & 378 & 372 \\
\hline & pizo 7 & 10.2 & 9530 & 4120 & 456 & 97 & 1234 & 1432 & 1500 & 1876 & 48.8 & 24 \\
\hline & pizo 8 & 7 & 5080 & 4640 & 520 & 154 & 700 & 1300 & 700 & 1300 & 494 & 0 \\
\hline Spring water & $\mathrm{Sp}$ & 11.6 & 14130 & 8400 & 987 & 345 & 1765 & 2034 & 1950 & 3040 & 1030 & 984 \\
\hline \multirow[t]{4}{*}{ Wand dam } & L1 & 7.7 & 988 & 593 & 101 & 25 & 72 & 190 & 50 & 190 & 157 & 4 \\
\hline & $\mathrm{L} 2$ & 7.9 & 990 & 598 & 102 & 25 & 75 & 188 & 55 & 188 & 159 & 4 \\
\hline & L3 & 7.6 & 988 & 595 & 101 & 24 & 74 & 190 & 53 & 190 & 155 & 4 \\
\hline & $\mathrm{L} 4$ & 7.57 & 980 & 595 & 99 & 28 & 70 & 188 & 57 & 178 & 153 & 4 \\
\hline \multirow{2}{*}{$\begin{array}{l}\text { Accumulation } \\
\text { Basins }\end{array}$} & Ac1 & 7.3 & 1368 & 645 & 134 & 20 & 66 & 255 & 50 & 240 & 134.2 & 0 \\
\hline & Ac7 & 7 & 2450 & 1050 & 189 & 36 & 150 & 401 & 150 & 401 & 189 & 0 \\
\hline \multirow{4}{*}{$\begin{array}{l}\text { Groundwater } \\
\text { Pumping wells }\end{array}$} & W1 & 7 & 3780 & 1650 & 201 & 65 & 400 & 450 & 309 & 450 & 274 & 6 \\
\hline & W2 & 7.1 & 3020 & 1905 & 245 & 79 & 470 & 523 & 240 & 440 & 176 & 12 \\
\hline & W3 & 7.22 & 2790 & 1620 & 211 & 68 & 343 & 435 & 210 & 390 & 256 & 6 \\
\hline & W4 & 6.86 & 2020 & 1596 & 267 & 69 & 334 & 489 & 150 & 350 & 268 & 6 \\
\hline Irrigation water & Ich & 7.53 & 1040 & 793 & 120 & 38 & 120 & 240 & 80 & 210 & 201 & 6 \\
\hline Unit & & & $\mu \mathrm{s} / \mathrm{cm}$ & \multicolumn{9}{|c|}{ Ppm } \\
\hline \multicolumn{13}{|c|}{ November, 2017} \\
\hline \multirow[t]{7}{*}{ piezometers } & pizo 1 & 7.4 & 4690 & 2415 & 450 & 102 & 186 & 2 & 279 & 980 & 112 & 4 \\
\hline & pizo 2 & 8.6 & 4456 & 2670 & 324 & 37 & 286.6 & 2 & 430 & 968 & 310 & 12 \\
\hline & pizo 3 & 9 & 3234 & 1595 & 287 & 44 & 220 & 1.4 & 330 & 962 & 44 & 22 \\
\hline & pizo 5 & 7.5 & 1534 & 775 & 103 & 23 & 62 & 1.7 & 93 & 381 & 180 & 3 \\
\hline & pizo 6 & 9.5 & 13232 & 5125 & 278 & 61 & 234.6 & 2 & 352 & 2454 & 350 & 256 \\
\hline & pizo 7 & 8.5 & 8900 & 4000 & 300 & 74 & 895.3 & 1.5 & 1343 & 1767 & 41 & 12 \\
\hline & pizo 8 & 6.9 & 4876 & 3490 & 480 & 120 & 408 & 1.6 & 612 & 1234 & 470 & 0 \\
\hline Spring water & $\mathrm{Sp}$ & 9 & 12673 & 7960 & 100 & 23 & 1249.3 & 1 & 1874 & 2890 & 978 & 765 \\
\hline \multirow[t]{4}{*}{ Wand dam } & L1 & 7.5 & 867 & 520 & 99 & 24 & 40 & 1.7 & 42 & 178 & 123 & 2 \\
\hline & $\mathrm{L} 2$ & 7.5 & 869 & 535 & 98 & 24 & 41 & 1.5 & 43 & 175 & 130 & 2 \\
\hline & L3 & 7.6 & 867 & 530 & 101 & 24 & 42 & 2 & 47 & 177 & 134 & 2 \\
\hline & $\mathrm{L} 4$ & 7.5 & 864 & 540 & 92 & 22 & 44 & 2 & 49 & 162 & 135 & 2 \\
\hline \multirow{2}{*}{$\begin{array}{l}\text { Accumulation } \\
\text { Basins }\end{array}$} & Ac1 & 6.9 & 1234 & 590 & 223 & 42 & 30.6 & 1.6 & 46 & 220 & 117 & 0 \\
\hline & Ac7 & 7 & 2234 & 900 & 478 & 151 & 85.3 & 2 & 128 & 378 & 165 & 0 \\
\hline \multirow{4}{*}{$\begin{array}{l}\text { Groundwater } \\
\text { Pumping wells }\end{array}$} & W1 & 7 & 3578 & 1500 & 520 & 169 & 191.3 & 2 & 287 & 387 & 250 & 3 \\
\hline & W2 & 7 & 2867 & 1750 & 584 & 188 & 151.3 & 2.2 & 227 & 378 & 155 & 4 \\
\hline & W3 & 7.1 & 2678 & 1470 & 445 & 169 & 118.6 & 2.1 & 178 & 345 & 234 & 3 \\
\hline & W4 & 6.8 & 1987 & 1445 & 267 & 68 & 84 & 1.9 & 126 & 322 & 245 & 3 \\
\hline Irrigation water & Ich & 7.3 & 1012 & 645 & 169 & 37 & 47.3 & 1.3 & 71 & 188 & 187 & 3 \\
\hline
\end{tabular}




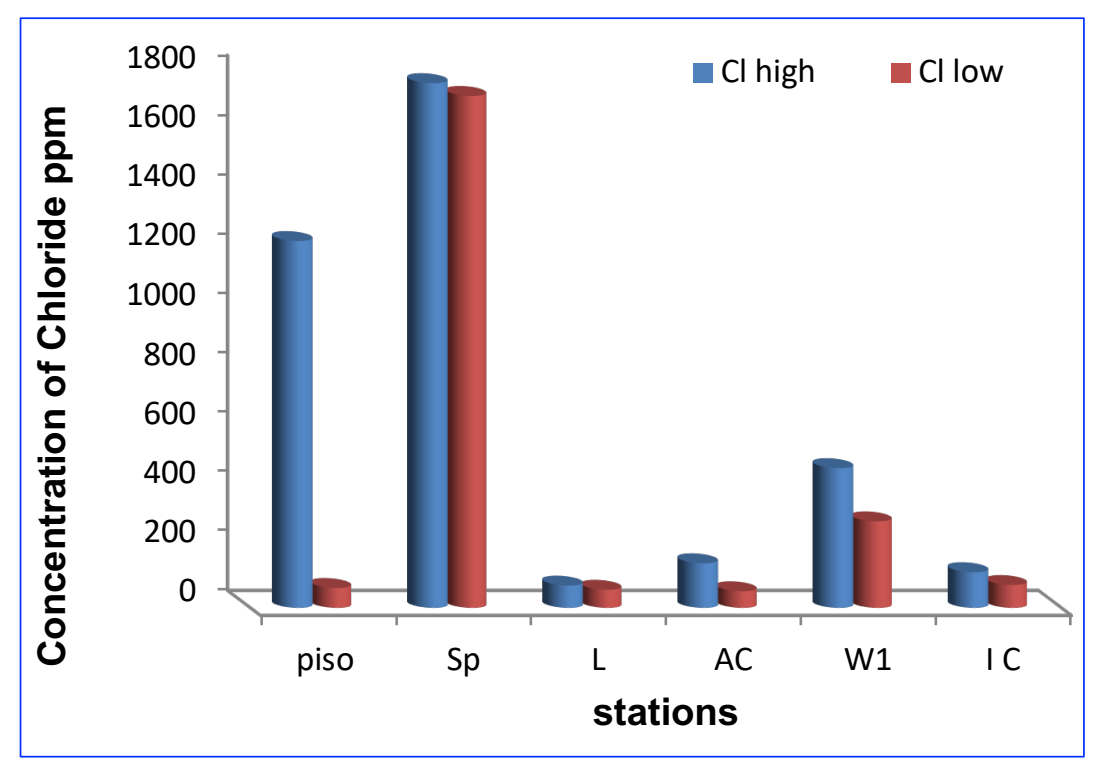

Fig. 3. Distribution of Cl-concentration in the study area for both periods, 2017

The concentrations of the major cations in the Wand dam water are of the order: $\mathrm{Ca}^{2+}>$ $\mathrm{Na}^{+}>\mathrm{Mg}^{2+}>\mathrm{K}^{+}$, whereas the anions have the order of: $\mathrm{SO}_{4}->\mathrm{Cl}->\mathrm{HCO}_{3}-$. The general water types are $\mathrm{CaSO}_{4}$ in both periods. While The concentrations of the major cations in accumulation basin, groundwater pumping wells, irrigation water and spring water are of the order: $\mathrm{Ca}^{2+}>\mathrm{Na}^{+}>\mathrm{Mg}^{2+}>\mathrm{K}^{+}, \mathrm{Na}>\mathrm{Ca}>\mathrm{Mg}^{2+}>\mathrm{K}^{+}, \mathrm{Ca}^{2+}>\mathrm{Na}^{+}>\mathrm{Mg}^{2+}>\mathrm{K}^{+}$and $\mathrm{Na}>\mathrm{Ca}>$ $\mathrm{Mg}^{2+}>\mathrm{K}^{+}$respectively, whereas the anions have the order of: $\mathrm{SO}_{4^{-}}>\mathrm{Cl}->\mathrm{HCO}_{3^{-}}, \mathrm{Cl}->\mathrm{SO}_{4}>$ $\mathrm{HCO}_{3}-, \mathrm{SO}_{4}->\mathrm{Cl}->\mathrm{HCO}_{3}, \mathrm{Cl}->\mathrm{SO}_{4}>\mathrm{HCO}_{3}$. The general water types in piezometer are $\mathrm{CaSO}_{4}$ except in pizo. 6 were $\mathrm{NaCl}$ in both periods June and November, 2017 (Fig. 4).

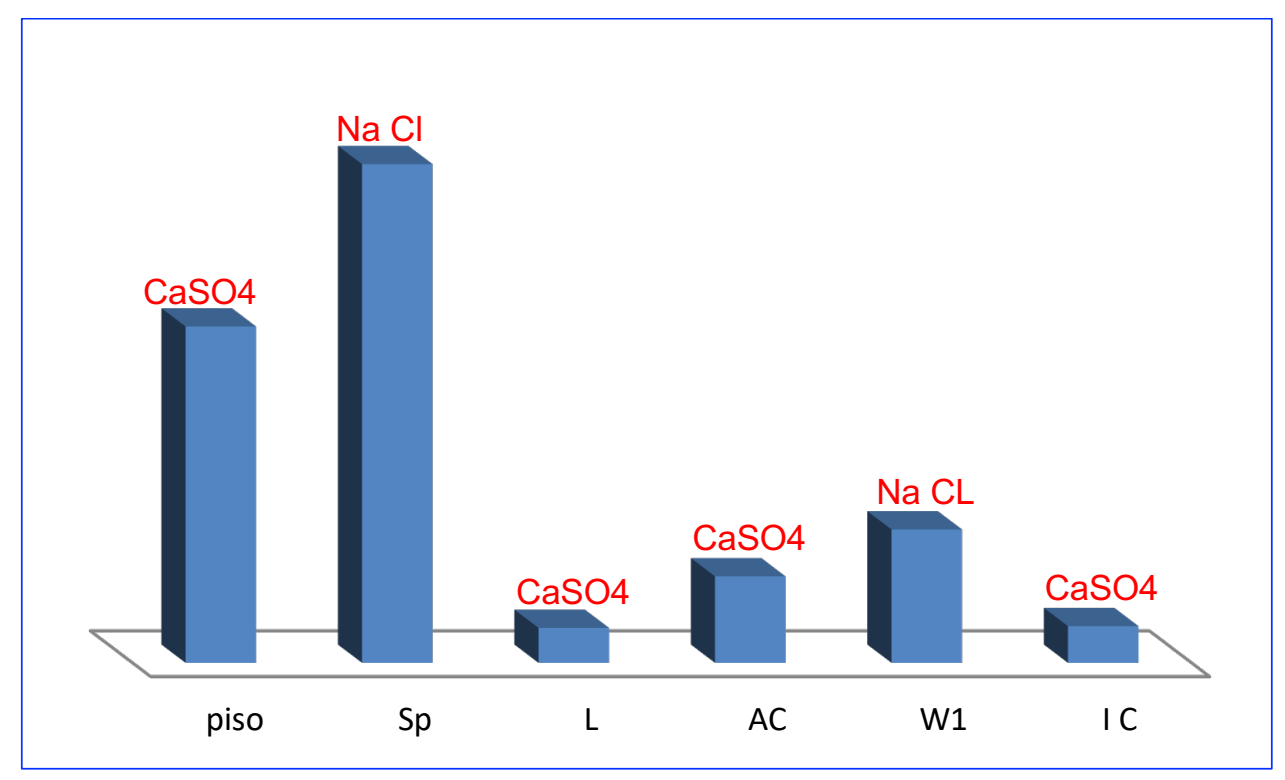

Fig. 4. Type of water for different water samples in the study area, 2017 
From the above results, it can be shown that there is spatial and temporal variation of TDS and ions of the studied area for the two study periods with the recharge variation, lithology, and climate conditions (rainfall and temperature). On the other hand, the spatial distribution of ions in groundwater pumping wells for two periods as a some of the major ion concentrations are of high ranges in the southwestern part Wand dam water more than the other part. This can be attributed to increasing of dissolution rate with the flow direction where the decreasing pattern of ions in the southwestern part may indicate high recharge rate.

\section{Isotopic Evaluation}

The $\delta^{18} \mathrm{O}$ and $\delta \mathrm{D}$ composition of water samples (Wand dam water accumulation basins, piezometer well, groundwater pumping wells were and irrigation water) in the study area were listed in Table 3. Wand dam water isotope data are collected at June and November, 2017 , show that values range from -4.93 to $-4.57 \%$ for ${ }^{18} \mathrm{O}$ and from -26.48 to $-23.96 \%$ o for ${ }^{2} \mathrm{H}$ in June, 2017. Stable isotope values measured in piezometers and groundwater pumping wells range from -5.75 to $+1.34 \%$, -3.85 to- 2.71 for ${ }^{18} \mathrm{O}$ and from -38.54 to $-4.34 \%$, 20.41to-13.37 for ${ }^{2} \mathrm{H}$ in June, 2019 respectively. In accumulation basins, spring water and irrigation water, isotopic values range from -4.46 to $-0.73 \%,-1.51 \%,-5.16 \%$ for ${ }^{18} \mathrm{O}$ and from -3.57 to $-2.88 \%,-2.468 \%$, $-3.8 \%$ o for ${ }^{2} \mathrm{H}$ in June, 2017 respectively, While the same variation in the November, the isotopic values in the Wand dam water range from -4.4 to $4.01 \%$ for ${ }^{18} \mathrm{O}$ and from -20.34 to $-19.49 \%$ o for ${ }^{2} \mathrm{H}$ in November, 2017. Stable isotope values measured in piezometers and groundwater pumping wells range from -6.31 to $+2.47 \%$, -3.86 to-2.21 for ${ }^{18} \mathrm{O}$ and from -27.37 to $-3.9 \%$, -15.32 to-12.2 for ${ }^{2} \mathrm{H}$ in November, 2019 respectively. In accumulation basins, Spring water and irrigation water, isotopic values range from -3.57 to $-2.88 \%$, $-2.46 \%$, $-3.8 \%$ for ${ }^{180}$ and from -15.56 to $-12.2 \%$, $-9.018 \%$, $22.97 \%$ or for ${ }^{2} \mathrm{H}$ in November. The Wand dam was most enriched in $\delta^{18} \mathrm{O}$ and $\delta^{2} \mathrm{H}$ isotopes with average values of $-4.50 \%$ and $-23.83 \%$, Respectively; The average values for groundwater pumping wells were $-3.53 \%$ and -18.34 for $\delta^{18} \mathrm{O}$ and $\delta^{2} \mathrm{H}$, Respectively. While average value of piezometers was $-4.62 \%$ for $\delta^{18} \mathrm{O}$ and -26.1 for $\delta^{2} \mathrm{H}$. The spatial variation of the isotopic values of the wand dam match with Piezometer $(3,4)$ and accumulation basin indicates there is no interaction between them. Fig. 5. shows that's all the samples of study area placed along both the global meteoric water lines (Craig, 1961) and local meteoric water lines (Al-Paruany, 2013), indicating that the rainfall is the recharge source of water resources in the study area, while some samples below the local meteoric water line (LMWL), indicating that experienced evaporation. 
Table 3. Isotopic values of the Wand dam, Piezometers and groundwater pumping wells, Others in the study area

\begin{tabular}{|c|c|c|c|c|c|c|c|}
\hline \multicolumn{2}{|c|}{ Stations } & \multicolumn{3}{|c|}{ June, 2017} & \multicolumn{3}{|c|}{ November, 2017} \\
\hline & & ${ }^{18} \mathrm{O}$ & ${ }^{2} \mathrm{H}$ & d-excess & ${ }^{18} \mathrm{O}$ & ${ }^{2} \mathrm{H}$ & d-excess \\
\hline \multirow[t]{7}{*}{ piezometers } & pizo 1 & -2.6 & -15.8 & 5 & -3.3 & -15.55 & 10.85 \\
\hline & pizo 2 & -4.8 & -29 & 9.4 & -5.17 & -26.47 & 14.89 \\
\hline & pizo 3 & -4.9 & -24.7 & 14.5 & -4.99 & -24.59 & 15.33 \\
\hline & pizo 5 & -5.7 & -38.5 & 7.1 & -4.12 & -27.37 & 5.59 \\
\hline & pizo 6 & -4.2 & -23.8 & 9.8 & -6.31 & -23.54 & 26.94 \\
\hline & pizo 7 & 1.3 & -4.3 & -14.7 & 2.47 & 3.9 & -15.86 \\
\hline & pizo 8 & -3.4 & -25.9 & 1.3 & -3.21 & -20.24 & 5.44 \\
\hline Spring water & $\mathrm{Sp}$ & -1.51 & -10.97 & 1.11 & -2.46 & -9.01 & 10.67 \\
\hline \multirow[t]{4}{*}{ Wand dam } & L1 & -4.57 & -23.9 & 12.66 & -4.02 & -19.9 & 12.26 \\
\hline & L2 & -4.74 & -26.4 & 11.52 & -4.01 & -20.2 & 11.88 \\
\hline & L3 & -4.6 & -25.3 & 11.5 & -4.05 & -20.3 & 12.1 \\
\hline & L4 & -4.93 & -24.6 & 14.84 & -4.4 & -19 & 16.2 \\
\hline \multirow{2}{*}{$\begin{array}{l}\text { Accumulation } \\
\text { basins }\end{array}$} & Ac1 & 0.73 & 13.61 & 7.77 & -2.88 & -14.58 & 8.46 \\
\hline & Ac7 & -4.46 & -20.74 & 14.94 & -3.57 & -15.56 & 13 \\
\hline \multirow{4}{*}{$\begin{array}{c}\text { Groundwater } \\
\text { Pumping wells }\end{array}$} & W1 & -2.71 & -13.3 & 8.38 & -2.21 & -12.2 & 5.48 \\
\hline & W2 & -3.37 & -16.7 & 10.26 & -3.86 & -14.75 & 16.13 \\
\hline & W3 & -3.49 & -17.9 & 10.02 & -3.64 & -15.32 & 13.8 \\
\hline & W4 & -3.8 & -20.41 & 9.99 & -3.42 & -15.32 & 12.04 \\
\hline Irrigation water & $\mathrm{IC}$ & -5.16 & -26.23 & 15.05 & -3.8 & -22.97 & 7.43 \\
\hline
\end{tabular}

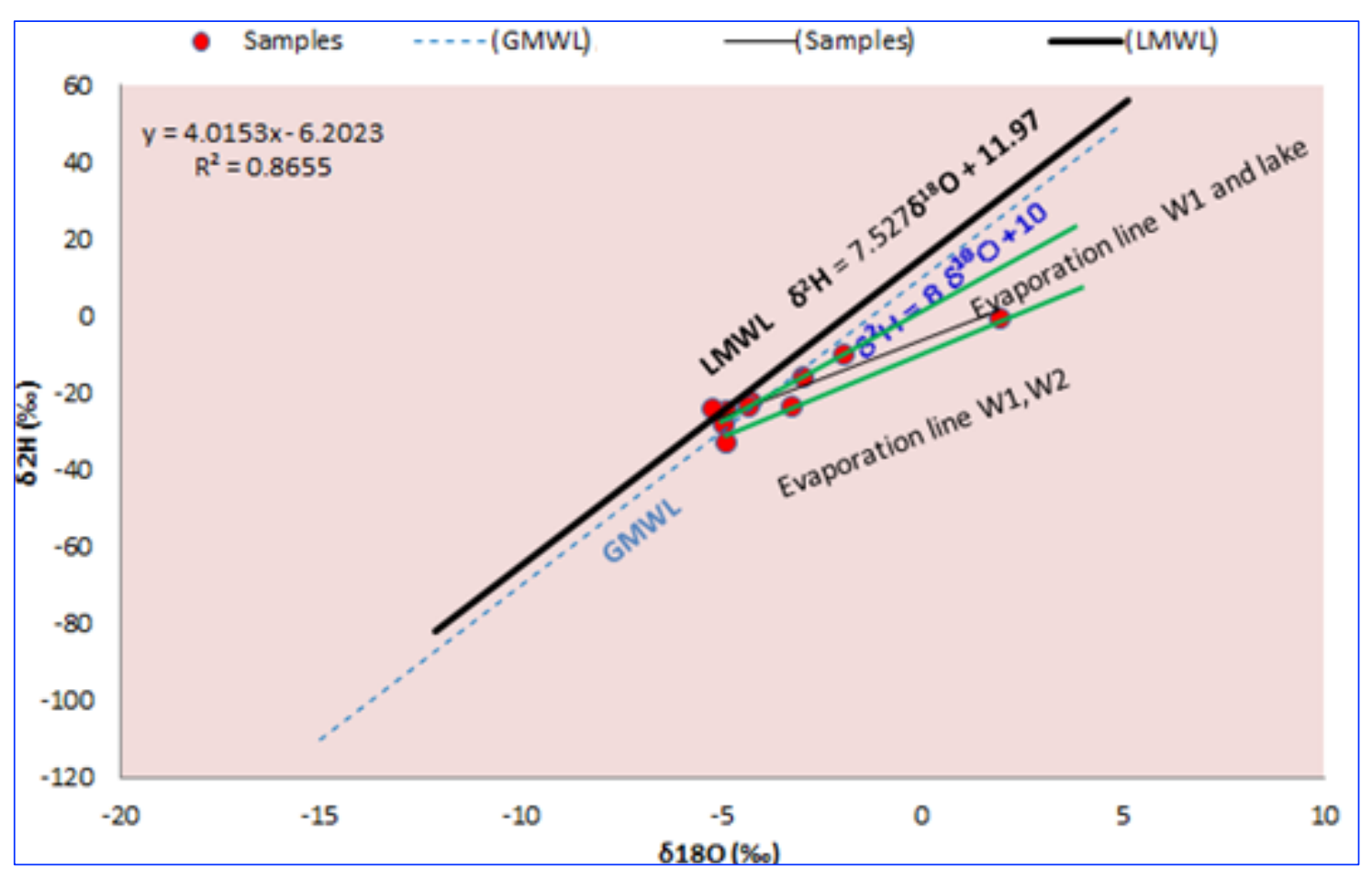

Fig. 5. Scatter plot between $\delta 2 H$ and $\delta 180$ and Meteoric water line (GMWL and LMWL) in various water bodies of the study area during June, and November 2017

From results above, three types of waters showed distinct isotopic compositions (Fig. 6). (i) group A, The Al-Wand dam water, piezometers 3 and 4, accumulation basin7, and irrigation water was with enriched isotopic composition ( $\delta \mathrm{D}:-23.8 \%$ and $\delta 18 \mathrm{O}:-4.50 \%$ ), and placed 
on the right of the LMWL, showing the effect of evaporation processes. (ii) group B, The Groundwater pumping wells and Pizo7 were plotted in two centralized locations, the enriched location for other piezometers due to differ in depth of wells. (III) group C, Accumulation basin and spring samples scattered along the GMWL and LMWL. The isotopic compositions of $\mathrm{AB} 1$ and spring became more and more depleted, would reflect different recharge conditions (from warm-cool temperature with low-high altitude). From the results above it can see that Piezometer 7 become more enriched may be effects by Al-Wand dam water.

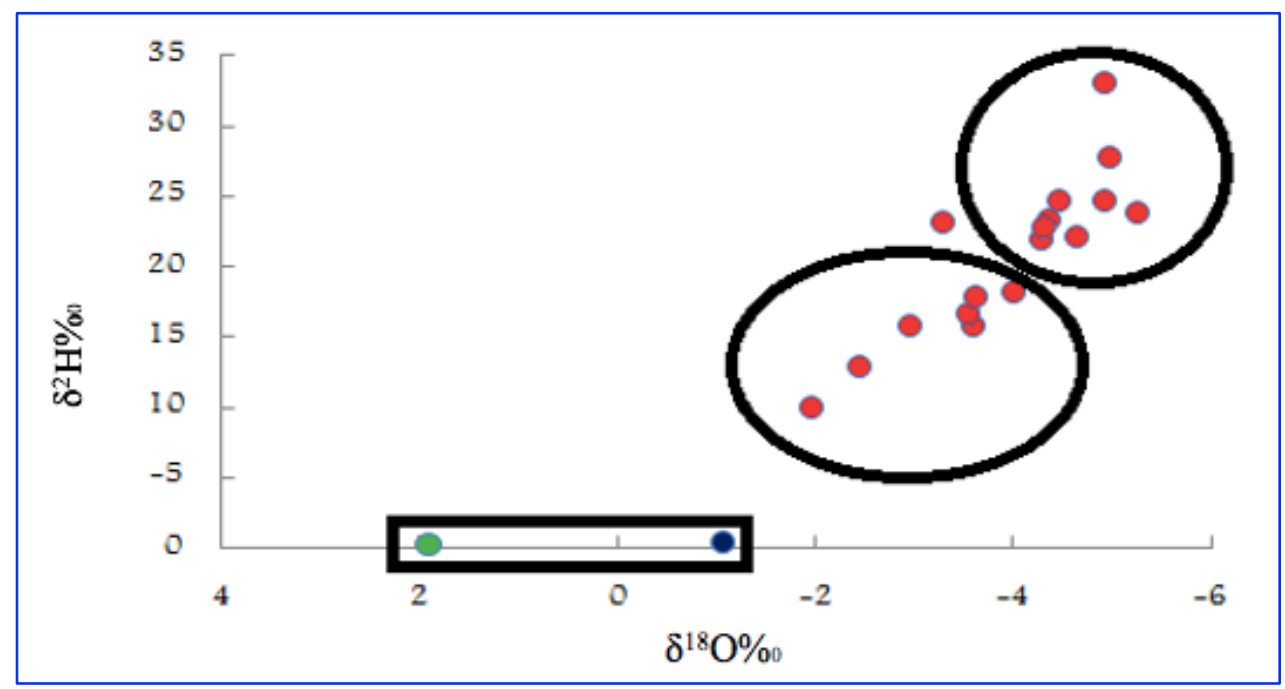

Fig. 6. Type of water in the study area according to isotopic values

The variations between the spring and pumping wells at station W1, W2 and W3 is almost 1.2 $\%$ o for $\delta^{18} \mathrm{O}$ and $9 \%$ for $\delta \mathrm{D}$, for both the spring and wells, show constant values during studied period. The isotopic values, as well as the diversity in electrical conductivity (2400 and $13234 \mu \mathrm{S} / \mathrm{cm}$ respectively) reflect the different groundwater pumping wells sources. Probably the spring ( $\mathrm{Sp}$ ) that it deeper than wells. Stable isotope values of the Wand dam water and other $(\mathrm{AC} 1,7)$ bodies are more enriched than those obtained from piezometer (except 5) and wells (W1, W2 and W3). suggesting that there is no recharge of groundwater and Wells by Al-Wand dam. The relationship between depths of water table with stable isotopic values of piezometers samples is significant on the effect of evapotranspiration. When the water level is near the surface, the water is subjected to evaporation. and leading to the loss of lighter water stable isotopes in the process. The stable isotope composition of piezometers groundwater samples against the depth to water table its clear there is a negative correlation. 


\section{EC and Isotopes}

Salinization in brackish water or highly saline water can be detected by plot the relation between ${ }^{18} \mathrm{O}$ and $\mathrm{EC}$ content. The enrichment of stable isotope due to evaporation, or increase of salinity due to leaching and/ or dissolution or mixing from the two cases could be defined (Mazor, 2004). This concept is based on that isotopic composition of groundwater under evaporation processes or mixing condition is necessarily accompanied with increasing in their isotopic content whereas salinization caused by dissolution of salt is not accompanied with change in isotopic composition .To define the mechanism of salinity in water bodies in study area a diagram plotted between $\delta^{18} \mathrm{O} \%$ and $\mathrm{EC}$ as seen in Fig. 7. This Fig shows that there is no clear relationship between $\mathrm{O}$ and $\mathrm{Ec}$ which indicates that the essential salinity in groundwater and Piezometers wells. The salinity of the Wand dam water is due to the dissolution and highly suffering of evaporation with no enough recharge of new fresh water from Iranian borders.

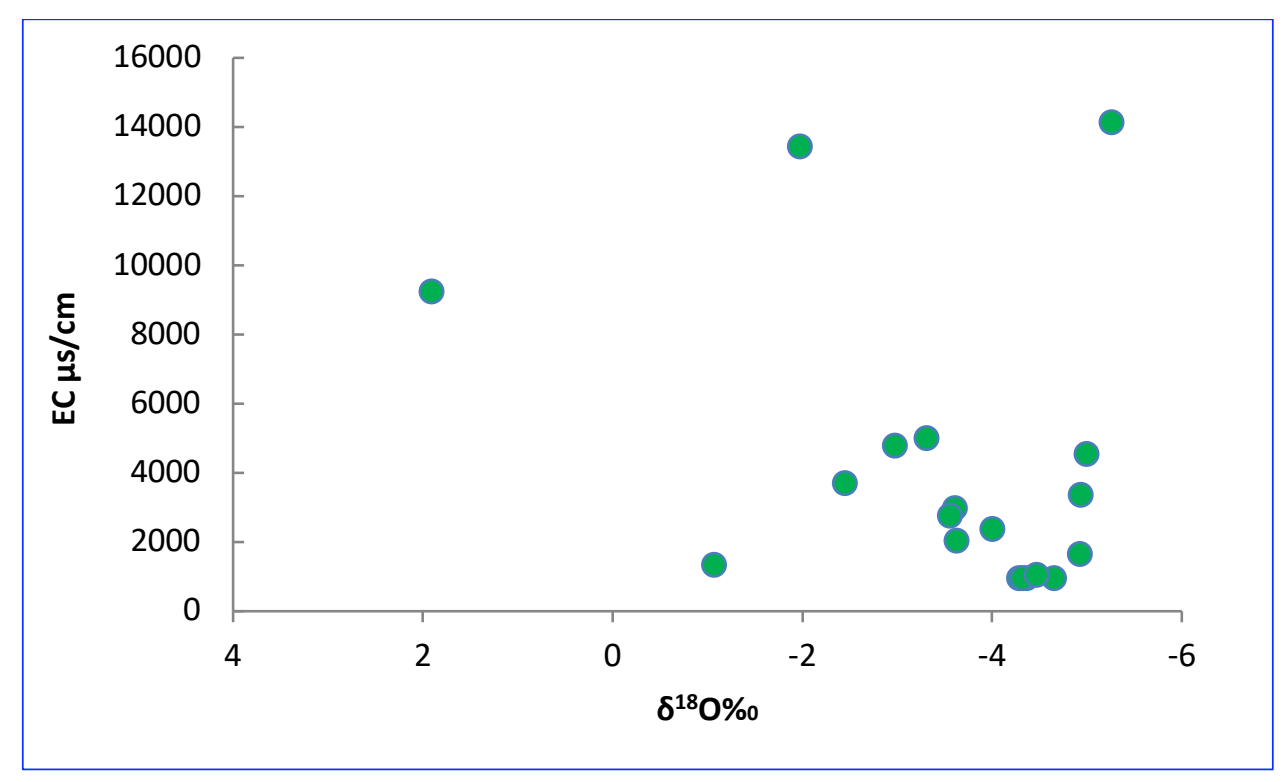

Fig. 7. Relationship between $O$ and Ec in the study area

The deuterium excess (d-excess), which was defined by Dansgaard (1964) was a one of the useful tools to study the water vapor sources, such as the humidity of vapor source or the evaporation effect during rainfall (Clark and Fritz, 1997). In the study area, the relationship between $\delta^{2} \mathrm{H}$ and $\delta^{18} \mathrm{O}$ for all water samples is shown in Fig. 8. d-excess of all water samples varied with a large scale from $-15.86 \%$ to $16.8 \%$. It was more than the intercept of GMWL (10\%) for most samples (11.21\%o-14.9\%o), except pizo.1 (7.9\%o), pizo. 5 (6.3\%), $\mathrm{AC} 1(8.11 \% 0)$, and Spring (5.89\%), this indicate that the primary evaporation process controlled in the vapor source region (Kendall, and Coplen, 2001). Samples of spring water 
are affected by the evaporation with high TDS (1232-15342mg/l). Finally, depend on chemical techniques and isotopic study in Al-Wand dam water, it clear that there is no connection between groundwater pumping wells and Al-wand dam except in Piezometer 5.

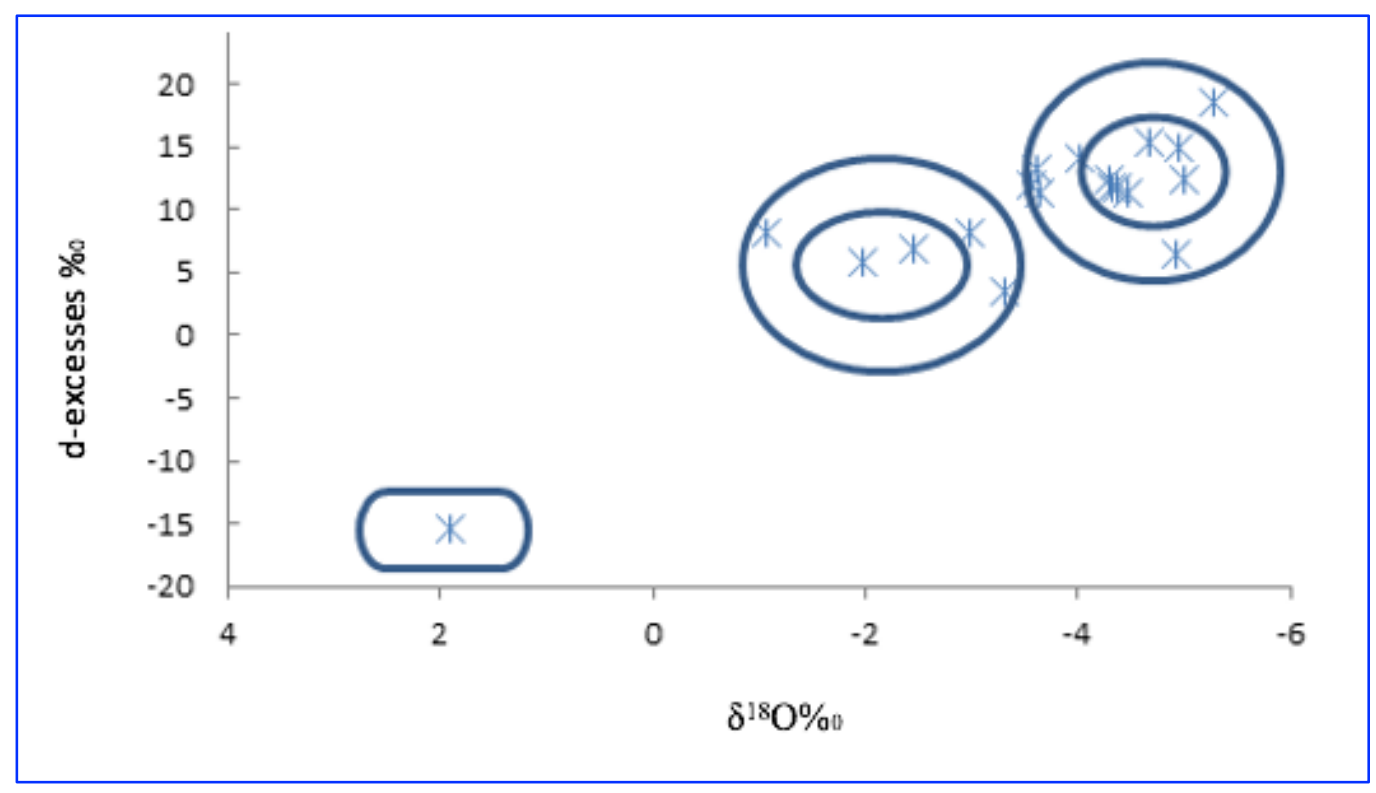

Fig. 8. variation d-excess in the study area

\section{CONCLUTIONS}

Based on environmental isotopes, it is noted the recharge source of groundwater pumping wells and Wand dam is rainfall. Also, there is direct recharge source to Wand dam by overland flow from Iranian borders. Water chemistry has been concluded based on interpretation of chemical analysis of the water samples collected over the study area. It is observed that groundwater and springs water have similar isotopic signatures and chemical facies in specific locations, which proved interconnection between groundwater aquifer and spring or/and could be the major source of spring recharge is groundwater. There are water samples of springs and groundwater have distinct chemical facies, then could be concluded that the recharge source is ancient exactly in the deep groundwater wells. By adopting piezometer No. 5, can be prove the interconnection between the groundwater and the water in Wand dam using radioactive isotopes in future $\left({ }^{3} \mathrm{H}\right.$ and $\left.{ }^{14} \mathrm{C}\right)$ to study the age of groundwater to investigate the patterns of recharge.

\section{ACKNOWLEDGMENTS}

The authors thank the staff of isotopic laboratory in Ministry of Science and Technology for their support during technical analysis. Our grateful thanks are also extended to Mr. Abdulkareem Al-Wazzan and Mr. Hani Saadi for his help in doing the chemical analysis. 
The authors are very grateful to the Editor in Chief Prof. Dr. Salih M. Awadh, the Secretary of Journal Mr. Samir R. Hijab and the Technical Editor Dr. Heba S. Al-Mimar for their great efforts and valuable comments.

\section{REFERENCES}

Abbas, D. A., 2019. Evaluation the interaction of Diyala River and groundwater in Jisr Diyala area within Baghdad city -Iraq. MSc. thesis, College of Science, University of Baghdad.

Ahmed, A.M., Mummad, A.A., and Dawood, K. S., 2005. Hydrogeological study of upper part of Diyala Basin, Ministry of Water Recourse, General Commission of Groundwater , 150p.

Ajena, A. R., 2014. Behavior of Natural Occurring Isotopes in Water Resources in Shanafiya-Samawa Area. MSc. thesis, College of Science, University of Baghdad.

Ali, S. M., 2012. Hydrogeological environmental assessment of Baghdad area, Ph.D. thesis, College of Science, University of Baghdad, $230 \mathrm{p}$.

Ali, K. K, and Ajena, A. R., 2016. Assessment of interconnection between surface water and groundwater in Sawa Lake area, southern Iraq, using stable isotope technique. Arabian Journal of Geoscience, 9:1-15.

Al-Jiburi, T. A. ,1991. Hydrological and Geomorphological study of the Diyala River. Ph.D. thesis, Collage of Science, University of Baghdad ,238 p. (in Arabic).

Al-Khafagi, Z. A., 2019. Application of Stable Isotope Technique in Estimating of Groundwater Mixing in AlNajaf-Ain- A 1-Tamur area. MSc. thesis, College of Science, University of Baghdad.

Al-Paruany, K. B., 2013. Hydro chemical and isotopic study of water resources between Haditha Dam and site of Al-Baghdadi Dam, Ph.D. thesis, University of Baghdad, College of Science, Baghdad, Iraq.

APHA, American Public Health association, American water works association (AWWA) and Water environmental Federation (WEF), 2012; Standard methods for the examination of water and wastewater, 22nd Edition, 9993p.

Applo, C. A. J., and Postmad, 2005, Geochemistry groundwater and pollution, 2nd edn. Balkema, Netherlands.

Awadh, S. M., Al-Kilabi, J. A., and Abdulhussein, F. M., 2016. Groundwater quality using water quality index in Al-Hawija area, Northern Iraq. Iraqi Geological Journal, 39 (1): 67-76.

Barnett, T. P., Adam, J. C., Lettenmaier, D. P., 2005. Potential impacts of a warming climate on water availability in snow-dominated regions, 438: 303-309.

Bath, A., Richards, H., Metcahfe, R., Littleboy, A., 2006. Geochemical indicators of deep groundwater movement at sellafied. Journal Geochemistry Exploration, 90:24-44.

Clark, I.D., Fritz, P., 1997. Environmental Isotopes in Hydrogeology. Lewis Publishers, New York.

Craig, H., 1961. Isotopic variations in meteoric waters. Science, 133 (3465):1702-1703.

Dansgaard, W., 1964. Stable isotopes in precipitation. Tellus 4, 436-468.

Esmail, T. H., 2012. Main rivers and valleys of Iraq, Turkey and Iran lands. Ministry of Water Resources, Baghdad, Iraq. (in Arabic).

Hadi, S. H., and Alwan, H. H., 2020. surface water-groundwater interaction in Diwaniya, southern Iraq using isotopic and chemical techniques. Iraqi Geological Journal, 53 (2B): 89-112.

IAEA. Isotopes in environmental studies. In Proceedings of an International Conference, Monaco. 2005.

Immerzeel, W. W., van Beek, L. P. H., Bierkens, M. F. P., 2010. Climate change will affect the Asian water towers. Science, 328: 1382-1385.

Jumaah, M. S., and Al-Shammaa, A. M., 2020. Hydrochemical assessment of groundwater of Euphrates aquifer in Anah, Western Iraq for irrigation purposes. Iraqi Geological Journal, 53 (2C): 121-133.

Kalbus, E., Reinstorf, F., Schirmer, M., 2006. Measuring methods for groundwater surface water interactions: a review. Hydrology Earth System Science,10(6): 873-887.

Kendall, C. and Coplen, T. B., 2001. Distribution of oxygen-18 and deuterium in river waters across the United States. Hydrological Processes, 15 (7): 1363-1393.

Liao, F., Wang, G. C., Shi, Z. M., Cheng, G. Q., Kong, Q. M., Mu, W. Q., Guo, L., 2018. Estimation of groundwater discharge and associated chemical fluxes into Poyang Lake, China: approaches using stable isotopes (delta D and delta O-18) and radon. Journal of Hydrogeology, 26 (5): 1625-1638. 
Mazor, E., 2004. Chemical and isotopic groundwater hydrology third edition. Weizmann Institute of Science Rehovot, New York, 465p.

National Center for Water Management, 2013. Discharges and water level data of Diyala and Al-Wand Rivers and Al- Wand reservoir Ministry of Water Resources, Report.

Ortega, G. A. 2003. Origin and geochemical evolution of groundwater in in a closed basin clayey aquitaed, Northern Mexico. Journal of Hydrology, 284:26-44.

Parsons, R. M., 1955. Groundwater Resources of Iraq, Khanaqin-Jassim area, Ministry of Development, Development Board, Iraq, 1:70.

Schmiedl, G., M. Pfeilsticker, C. Hemleben, and A. Mackensen. 2004. Environmental and biological effects on the stable isotope composition of recent deep-sea benthic foraminifera, from the western Mediterranean Sea. Marine Micropaleontology, 51: 129-152.

Zhou, J., et al., 2016. Application of hydrochemistry and stable isotopes $(\delta 34 \mathrm{~S}, \delta 18 \mathrm{O}$ and $\delta 37 \mathrm{Cl})$ to trace natural and anthropogenic influences on the quality of groundwater in the piedmont region, Shijiazhuang, China. Applied Geochemistry, 71, 63-72. doi:10.1016/j. apgeochem.2016.05.018. 